Florida International University FIU Digital Commons

FCE LTER Journal Articles

FCE LTER

2001

\title{
Biogeochemical effects of iron availability on primary producers in a shallow marine carbonate environment
}

\author{
Randolph M. Chambers \\ Biology Department and Virginia Institute of Marine Science, College of William and Mary \\ James W. Fourqurean \\ Department of Biological Sciences and Southeast Environmental Research Center, Florida International University, \\ fourqure@fiu.edu
}

Stephen A. Macko

Department of Environmental Sciences, University of Virginia

Biology Department, Fairfield University

Follow this and additional works at: https://digitalcommons.fiu.edu/fce_lter_journal_articles

\section{Recommended Citation}

Chambers, R.M., J.W. Fourqurean, S.A. Macko, R. Hoppenot. 2001. Biogeochemical effects of iron availability on primary producers in a shallow marine carbonate environment. Limnology and Oceanography 46(6): 1278-1286.

This material is based upon work supported by the National Science Foundation through the Florida Coastal Everglades Long-Term Ecological Research program under Cooperative Agreements \#DBI-0620409 and \#DEB-9910514. Any opinions, findings, conclusions, or recommendations expressed in the material are those of the author(s) and do not necessarily reflect the views of the National Science Foundation. This work is brought to you for free and open access by the FCE LTER at FIU Digital Commons. It has been accepted for inclusion in FCE LTER Journal Articles by an authorized administrator of FIU Digital Commons. For more information, please contact dcc@fiu.edu, jkrefft@fiu.edu. 


\title{
Biogeochemical effects of iron availability on primary producers in a shallow marine carbonate environment
}

\author{
Randolph M. Chambers ${ }^{1}$ \\ Biology Department and Virginia Institute of Marine Science, College of William and Mary, Williamsburg, Virginia
} 23187

James W. Fourqurean

Biology Department and Southeast Environmental Research Center, Florida International University, Miami, Florida 33199

Stephen A. Macko

Department of Environmental Sciences, University of Virginia, Charlottesville, Virginia 22903

\author{
Regis Hoppenot \\ Biology Department, Fairfield University, Fairfield, Connecticut 06430
}

\begin{abstract}
We completed a synoptic survey of iron, phosphorus, and sulfur concentrations in shallow marine carbonate sediments from south Florida. Total extracted iron concentrations typically were $<50 \mu \mathrm{mol} \mathrm{g}^{-1}$ dry weight (DW) and tended to decrease away from the Florida mainland, whereas total extracted phosphorus concentrations mostly were $<10 \mu \mathrm{mol} \mathrm{g}{ }^{-1} \mathrm{DW}$ and tended to decrease from west to east across Florida Bay. Concentrations of reduced sulfur compounds, up to $40 \mu \mathrm{mol} \mathrm{g}^{-1} \mathrm{DW}$, tended to covary with sediment iron concentrations, suggesting that sulfide mineral formation was iron-limited. An index of iron availability derived from sediment data was negatively correlated with chlorophyll $a$ concentrations in surface waters, demonstrating the close coupling of sediment-water column processes. Eight months after applying a surface layer of iron oxide granules to experimental plots, sediment iron, phosphorus, and sulfur were elevated to a depth of $10 \mathrm{~cm}$ relative to control plots. Biomass of the seagrass Thalassia testudinum was not different between control and iron addition plots, but individual shoot growth rates were significantly higher in experimental plots after 8 months. Although the iron content of leaf tissues was significantly higher from iron addition plots, no difference in phosphorus content of T. testudinum leaves was observed. Iron addition altered plant exposure to free sulfide, documented by a significantly higher $\delta^{34} \mathrm{~S}$ of leaf tissue from experimental plots relative to controls. Iron as a buffer to toxic sulfides may promote individual shoot growth, but phosphorus availability to plants still appears to limit production in carbonate sediments.
\end{abstract}

The effect of iron limitation on growth of primary producers in marine systems has been shown for phytoplankton (Martin and Fitzwater 1988; Barber and Chavez 1991; Coale et al. 1996) and suggested for seagrasses growing in carbonate sediments (Duarte et al. 1995). In addition to its observed biochemical effects on photosynthesis (Geider et al. 1993) and suspected control of nitrogen fixation (Wu et al. 2000), iron participates in at least two other geochemical reactions influencing primary production in marine systems. First, reactive iron can serve as a sorption site for inorganic phosphate, thereby changing the availability of phosphorus

\footnotetext{
' Corresponding author (rmcham@wm.edu).
}

\section{Acknowledgments}

Sediment samples from the southwest Florida shelf were obtained by Brad Peterson and the SERC seagrass monitoring team. Thanks to Kevin Cunniff, Lisa Millman, Toru Endo, Susie Escorcia, and Dana Madeux for field and lab assistance. Principal funding for the project was provided by National Park Service grant CA5280-79024; additional funding for laboratory analysis and data interpretation was provided by Florida Coastal Everglades LTER (NSF/ OCE-9910514). This is contribution 148 from the Southeast Environmental Research Center. to benthic primary producers (Jensen et al. 1998) and retarding the release of $\mathrm{P}$ from the sediments to the overlying water column (Chambers et al. 1995). Second, iron may react with sediment sulfides, precipitating them as iron-sulfur minerals and "buffering" the effects of toxic sulfides on primary producers (Carlson et al. 1994; Terrados et al. 1999; Erskine and Koch 2000). Because of both direct and indirect effects of iron on the growth of plants and algae, the distribution and availability of iron in different marine environments are important variables influencing the structure of ecosystems.

A marine system ideal for studying the distribution and geochemical effects of iron is the shallow carbonate environment, where relative to terrigenous systems, the concentrations of iron are very low (Duarte et al. 1995). Pyrite formation typically is iron-limited in marine carbonate environments (Berner 1984), and free sulfides produced as a by-product of sulfate reduction tend to accumulate to high concentrations (Barber and Carlson 1993). In biogenic sediments without much iron, $\mathrm{P}$ sorption to calcium carbonate minerals is the principal mechanism for maintaining low $\mathrm{P}$ concentrations in solution (Rosenfeld 1979; Morse et al. 1985 ) and rendering primary producers P-limited (Powell et 
al. 1989; Fourqurean et al. 1992a, 1993; Erftemeijer 1994). By reducing sulfide toxicity and contributing to phosphorus limitation, however, the geochemical behavior of iron could create conditions that simultaneously enhance and decrease plant production. To date, the relative effects of sulfide toxicity and phosphorus limitation on primary production in iron-poor environments are unknown.

In the present study, we determined the surface sediment concentrations of iron, phosphorus, and sulfur throughout carbonate environments of south Florida, in areas vegetated by rooted seagrasses (Florida Bay), and by calcareous algae (southwest Florida shelf). We also compared the availability of reactive iron in sediments with water column primary production. Finally, we measured the effects of iron enrichment on phosphorus retention, toxic sulfide buffering, and seagrass production from a site in Florida Bay. Overall, our goal was to determine the dual geochemical influence of iron on sulfur and phosphorus in carbonate sediments and to evaluate the potential effect on primary producers.

\section{Materials and methods}

Site description-The study was completed by sampling carbonate sediments located in Florida Bay and the adjacent southwest Florida shelf in the Gulf of Mexico $\left(\sim 24.5^{\circ} \mathrm{N}\right.$, $81.0^{\circ} \mathrm{W}$ ). Florida Bay, as defined by the shallow marine/estuarine environment bordered on the north by the mainland of Florida, on the southeast by the Florida Keys island chain, and on the west by the boundary of Everglades National Park, is a very shallow ( $<2 \mathrm{~m}$ deep) embayment generally lined by fine-grained carbonate sediments supporting seagrass beds, dominated by Thalassia testudinum. A strong gradient of decreasing seagrass biomass and primary production from west to east in Florida Bay is a consequence of decreasing $\mathrm{P}$ availability in pore water along the same gradient (Fourqurean et al. 1992a,b).

The 51 sampling stations on the southwest Florida Shelf were all located in less than $20 \mathrm{~m}$ of water and typically had muddy-sand carbonate sediments and sparse macroalgal communities instead of seagrasses. Twenty of the 24 stations sampled in Florida Bay make up a portion of the Florida Bay monitoring program that has tracked surface water quality since 1989 (Fourqurean et al. 1993; Boyer et al. 1997, 1999); we obtained data on the mean chlorophyll $a(\mathrm{Chl} a$ ) concentrations in the water column at the 20 Florida Bay stations for the period June 1989-July 1999 from this monitoring program.

Synoptic survey for iron, phosphorus, and sulfur-At all 75 stations, $0.5-\mathrm{ml}$ sediment samples were collected in duplicate or triplicate using an open-end 3-ml syringe pushed $1 \mathrm{~cm}$ into the sediment surface. Samples were placed in tared glass vials, capped, and kept on ice prior to laboratory analysis for bulk sediment properties and extractable iron and phosphorus. A second set of $0.5-\mathrm{ml}$ sediment samples was placed in $3 \mathrm{ml}$ of $1 \mathrm{M}$ buffered zinc acetate solution to stabilize reduced sulfur compounds prior to laboratory extraction and analysis.

Samples for bulk sediment properties were weighed wet, oven dried at $80^{\circ} \mathrm{C}$ for $4 \mathrm{~d}$, weighed to determine dry bulk density, then ashed at $450^{\circ} \mathrm{C}$ for $5 \mathrm{~h}$. For sediments collected from the southwest Florida shelf, the ashed samples were resuspended in $10 \mathrm{ml}$ of $1 \mathrm{~N} \mathrm{HCl}$ and placed on a shaker table for $24 \mathrm{~h}$. This concentration of acid was sufficient to dissolve the carbonate matrix of the sediments and associated iron monosulfides but did not dissolve more resistant iron sulfide compounds such as pyrite. The solution was filtered (Whatman GFC) and the filtrate was analyzed colorimetrically for iron $(\mathrm{Fe})$ and phosphorus $(\mathrm{P})$ using standard methods. $\mathrm{HCl}-\mathrm{Fe}$ and total extracted $\mathrm{P}$ were determined on these samples. For sediments collected from Florida Bay, $\mathrm{HCl}-\mathrm{Fe}$ and total extracted $\mathrm{P}$ were determined by summing the results of a four-step sequential extraction scheme for sediments modified after Jensen et al. (1998). The four fractions included iron and phosphorus sequentially extracted by $1 \mathrm{~N} \mathrm{MgCl}_{2}$, buffered citrate-dithionite (BD), buffered acetate (Ac), and $1 \mathrm{~N} \mathrm{HCl}$. Furthermore, we defined the "reactive iron" fraction as the sum of $\mathrm{MgCl}_{2}-\mathrm{Fe}+\mathrm{BD}-\mathrm{Fe}+\mathrm{Ac}-\mathrm{Fe}$, with more chemically resistant detrital iron extracted by the final $\mathrm{HCl}$ step.

A two-step extraction scheme was completed to determine total sediment sulfide concentrations (Chambers et al. 1994). Acid-volatile sulfide (AVS) was extracted with $1 \mathrm{~N} \mathrm{HCl}$ and included free dissolved sulfide and iron monosulfide (FeS); chromium-reducible sulfide (CRS) was extracted with boiling, reduced chromium/concentrated $\mathrm{HCl}$ and was assumed to be pyrite $\left(\mathrm{FeS}_{2}\right)$. The concentration of CRS-Fe, therefore, was half the concentration of CRS and was added to $\mathrm{HCl}-$ $\mathrm{Fe}$ to calculate total extracted $\mathrm{Fe}$ in sediment.

Spatially interpolated maps of the concentrations of total extracted iron, phosphorus, and sulfide in surface sediments were produced using a kriging algorithm (point kriging, isotropic linear variogram model with no drift and no nugget).

Iron enrichment experiment-The effects of iron addition to carbonate sediments were measured in a dense $T$. testudinum seagrass bed in water $1 \mathrm{~m}$ deep in Rabbit Key Basin, western Florida Bay $\left(24^{\circ} 58.8^{\prime} \mathrm{N}, 80^{\circ} 50.8^{\prime} \mathrm{W}\right)$. In November 1998 , three $0.25-\mathrm{m}^{2}$ plots were established for iron enrichment; three adjacent plots served as controls. To each of the

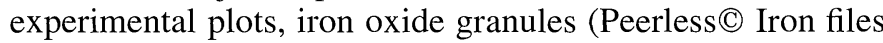
ETI $8 / 50$, surface area $1.2944 \mathrm{~m}^{2} \mathrm{~g}^{-1}$ ) were shaken out and spread to a density of approximately $0.5 \mathrm{~g} \mathrm{~cm}^{-2}$. In November (prior to iron addition), 2 months after addition (January 1999) and 8 months after addition (July 1999), sediment cores to a depth of $30 \mathrm{~cm}$ were collected from each of the control and experimental plots. Subcores were then taken at intervals of $2.5-5 \mathrm{~cm}$ down the length of each core; $0.5-\mathrm{ml}$ sediment samples were collected for determinations of bulk sediment properties and for $\mathrm{HCl}-\mathrm{Fe}$, total $\mathrm{P}$, and total sulfide concentrations using analytical procedures described for surface sediments.

The response of the seagrass to iron additions was determined in January and July 1999 by biomass and growth measures. Net aboveground productivity of $T$. testudinum was measured in both January and July 1999 at each experimental and control plot using a modified leaf marking tech-

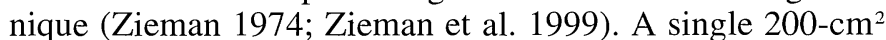
quadrat was placed arbitrarily in each plot; within each quadrat, all short shoots of the seagrass $T$. testudinum were 
marked by driving an 18-gauge hypodermic needle through the base of the leaves. Care was taken not to disturb other plant and animal taxa in the quadrats. The marked short shoots were allowed to grow for 10-14 d, after which all aboveground seagrass material in the quadrats was harvested. Plant material was separated by seagrass species, and leaves of all species were counted, measured (length and width to nearest $\mathrm{mm}$ ), cleaned of epiphytes by gentle scraping, and dried to constant mass at $70^{\circ} \mathrm{C}$. We quantified $T$. testudinum standing crop as the dry weight of green leaves per square meter and productivity as dry weight of green leaves produced per short shoot per day.

Because phosphorus content in seagrass leaves is a good proxy for the availability of $\mathrm{P}$ to plants (Fourqurean et al. $1992 a$ ), we measured $\mathrm{P}$ content of leaves collected from both experimental and control plots in January and July 1999. From each plot, five intact short shoots of T. testudinum were collected arbitrarily; when Halodule wrightii was present, we collected 20 intact short shoots, which were returned to the lab. All attached green leaves were cut from the short shoots and cleaned of adhering epiphytes by gently scraping with a razor blade. All leaves from a site were pooled and dried at $80^{\circ} \mathrm{C}$. Dried leaves were ground to a fine powder using a ceramic mortar and pestle. Powdered samples were analyzed in duplicate using a dry oxidation, acid hydrolysis extraction followed by a colorimetric analysis for phosphate (Fourqurean et al. 1992a). To determine whether iron enrichment of sediments would lead to increased Fe uptake by plants, the $\mathrm{Fe}$ content of leaves was determined using a similar oxidation/acid extraction and colorimetric analysis scheme.

Plant exposure to sulfide stress was measured by determining the stable sulfur isotopic signature of leaf tissue. Sediment sulfides are generated by microbial sulfate reduction, a process that fractionates sulfur isotopes very strongly (Chambers and Trudinger 1979). The sulfide pool is depleted in the heavier ${ }^{34} \mathrm{~S}$ isotope relative to the source sulfate. This fractionation provides a tool for examining the relative effect of sulfides on plants, because the stable sulfur isotopic composition of plant tissues is determined by the sulfur source (Carlson and Forrest 1982; Stribling et al. 1998). We hypothesized that with removal of isotopically lighter sulfide via authigenic pyrite formation in iron addition plots, an increase in the $\delta^{34} \mathrm{~S}$ content of seagrass leaves would indicate an alleviation of sulfide exposure.

Samples of dried seagrasses were converted to $\mathrm{SO}_{2}$ for isotope analysis using a Carlo Erba elemental analyzer (EA) coupled to an OPTIMA stable isotope ratio mass spectrometer (Micromass). In the EA, the organic sulfur is pyrolyzed at $1,050^{\circ} \mathrm{C}$ using a combination oxidation and reduction furnace system. The resulting $\mathrm{SO}_{2}$ gas is chemically dried and injected directly into the source of the mass spectrometer. The stable isotopic ratio is reported as

$$
\delta^{34} \mathrm{~S}=\left[R_{\text {sample }} / R_{\text {standard }}-1\right] \times 10^{3}(\%),
$$

where $R$ is the abundance ratio of the heavy to light isotopes $\left.{ }^{(34} \mathrm{S} /{ }^{32} \mathrm{~S}\right)$ of sulfur and is corrected for the mass overlap with the isotopes of oxygen. The international standard for ${ }^{34} \mathrm{~S}$ is the Canyon Diablo Troilite (CDT), which is assigned a $\delta^{34} \mathrm{~S}$ value of $0.0 \%$. The reproducibility of the measurement typically is better than $\pm 0.2 \%$ o when using the continuous flow interface on the OPTIMA. In the laboratory, the samples are commonly measured against a sulfur dioxide gas that has been calibrated against NBS 127.

Results of the iron addition experiments were analyzed using ANOVA with significance level $P \leq 0.05$. We treated time and treatment as main effects; we did not use a repeated measures design because we did not sample the same short shoots each sampling interval, nor did we record the plot within a treatment from which each sample originated.

\section{Results}

Synoptic survey of iron, phosphorus, and sulfur-Relative to terrigenous sediments, total extracted $\mathrm{Fe}$ concentrations in Florida Bay were extremely low and exhibited a strong gradient of decreasing concentration away from the Florida mainland (Fig. 1). The concentrations in Florida Bay ranged from a high of $66 \mu \mathrm{mol} \mathrm{g}^{-1}$ dry weight (DW) in the northeast corner of Florida Bay to a low of $5.2 \mu \mathrm{mol} \mathrm{g}^{-1} \mathrm{DW}$ at the southern bay boundary. Fe concentrations on the southwest Florida shelf, in contrast, generally were lower and exhibited no clear gradient. Some higher concentrations were measured nearest the western coast of Florida, and a distinct region of low concentration was found west of the Florida mainland.

Sediment concentrations of total $\mathrm{P}$ from the southwest Florida shelf were distributed in a pattern similar to iron, with low concentrations found west of the Florida mainland and higher concentrations near the coast and along the western boundary of Florida Bay (Fig. 1). A gradient of decreasing sediment phosphorus concentrations, however, was observed from west to east across Florida Bay.

On average, most of the reduced sulfur compounds in sediments were extracted as CRS, with $<10 \%$ as AVS. Total sediment sulfide concentrations were higher in Florida Bay than from the southwest Florida shelf and generally higher near the Florida mainland (Fig. 1).

For Florida Bay, we plotted the distributions of reactive $\mathrm{Fe}$ and CRS-Fe and then calculated an index of iron availability (Fig. 2). The index measures the degree of sulfidization (Chambers et al. 2000) and computes the fraction of the iron pool available for reaction with free sulfides (i.e., reactive $\mathrm{Fe} /[$ reactive $\mathrm{Fe}+\mathrm{CRS}-\mathrm{Fe}]$ ). The small amount of AVS-Fe relative to CRS-Fe could not be determined and included in the calculation, so the index is a slight overestimate of iron availability. Lowest values of the index occurred in the north-central basin of Florida Bay, where the capacity of reactive iron to buffer sulfide toxicity via ironsulfide mineral formation is diminished. In contrast, the highest values of the index occurred along the western margin and in the northeastern portions of the bay.

We then compared the sediment index of iron availability with the 1997-1998 annual average water column Chl $a$ concentrations obtained from the Florida Bay water quality monitoring program (Boyer et al. 1997, 1999). The index was negatively correlated with water column Chl $a$ concentrations $\left(r^{2}=0.54\right)$ (Fig. 3). Higher indices of reactive iron availability in sediments occurred where water column concentrations of Chl $a$ were low. 

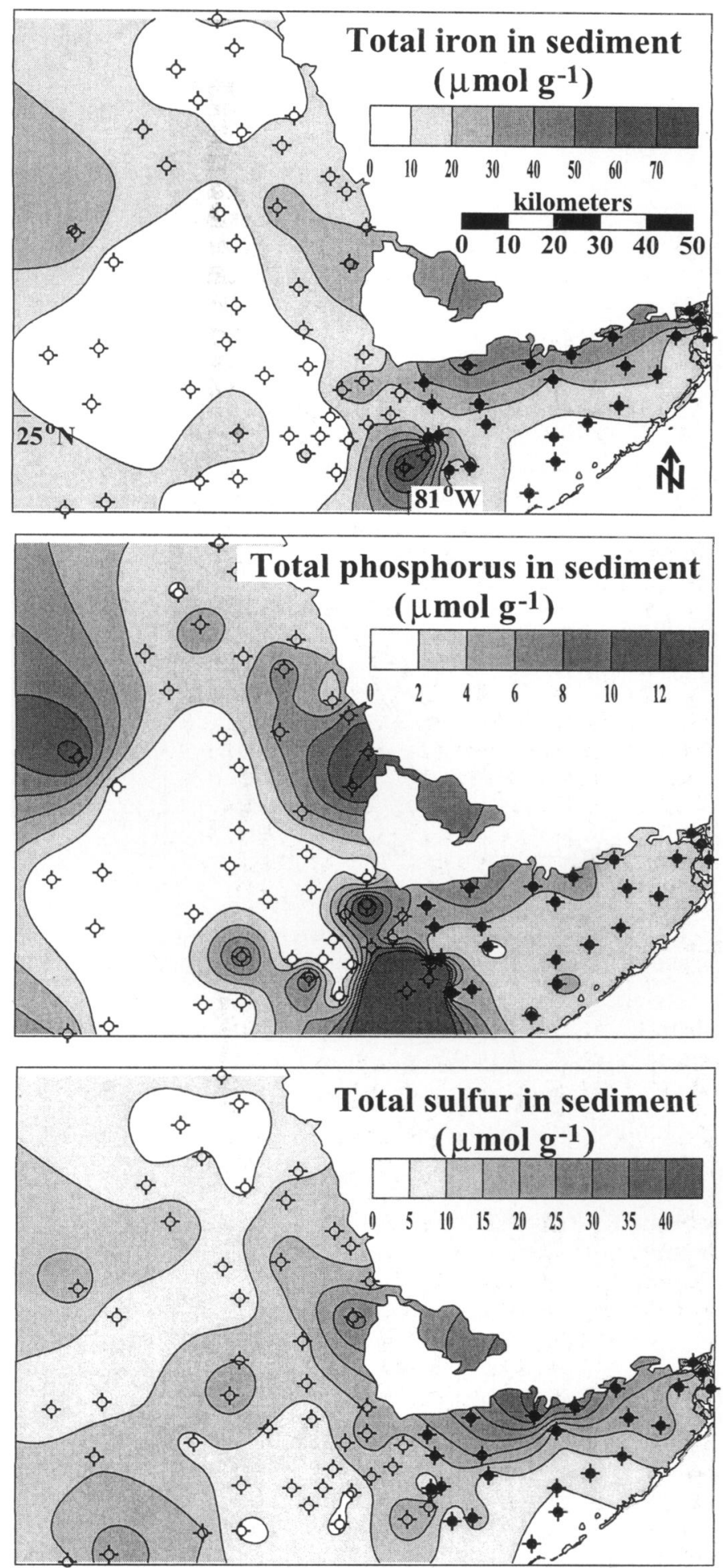

Fig. 1. Synoptic survey of total Fe, P, and S from surface sediments throughout shallow marine/estuarine environments in south Florida ( $\mu \mathrm{mol} \mathrm{g}^{-1}$ dry weight). Isopleths of equal concentration were generated by spatial interpolation around data collected from the 75 sampling stations shown. The south Florida mainland is shown in white; open symbols are sample sites from the southwest Florida shelf, and closed symbols are sample sites from Florida Bay.
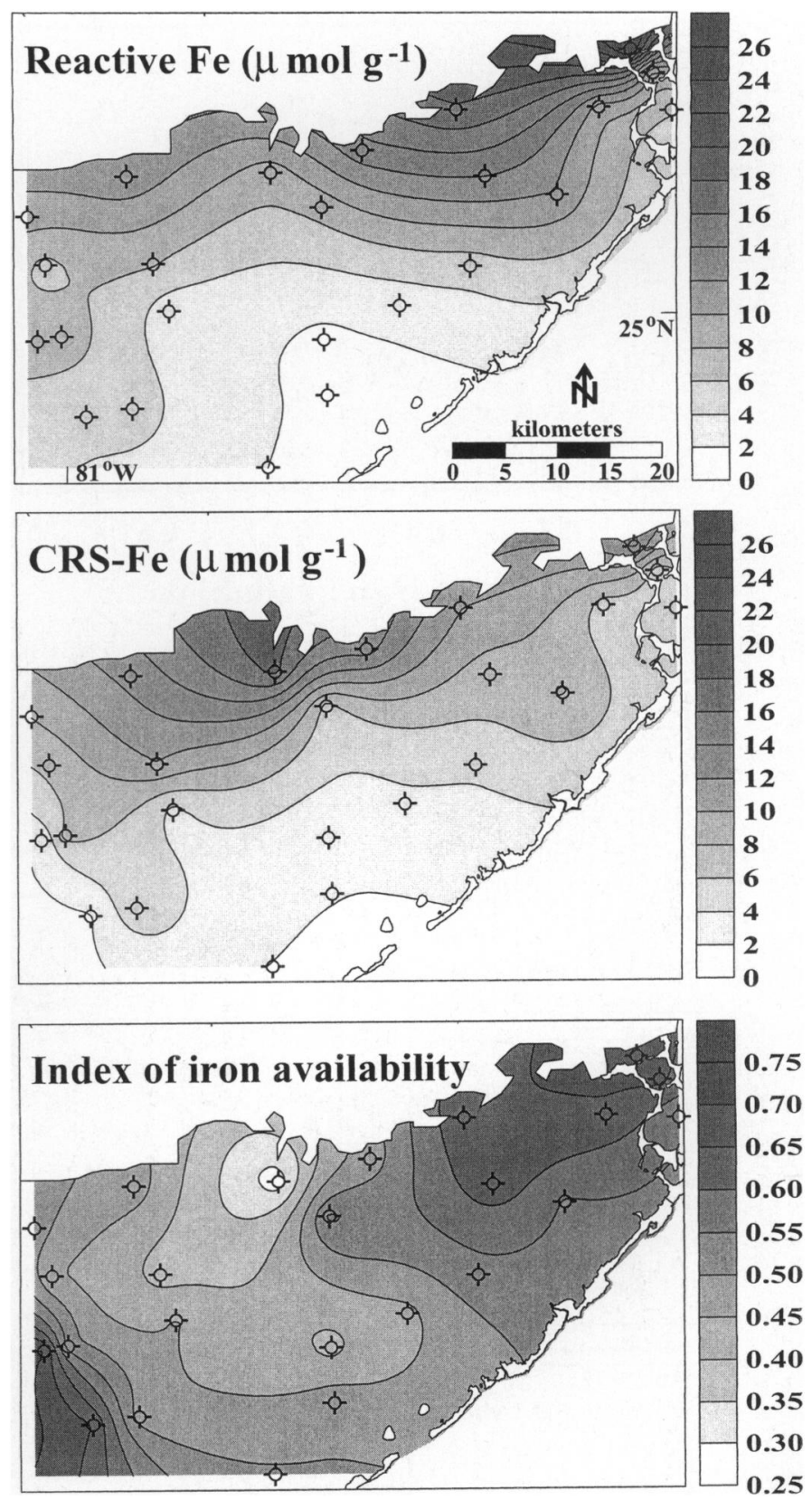

Fig. 2. Synoptic survey of reactive Fe and CRS-Fe throughout

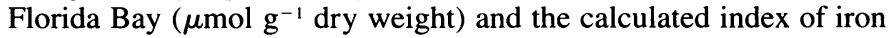
availability. Isopleths of equal value were generated by spatial interpolation around data collected from the 24 sampling stations shown.

Iron enrichment experiment-In January, 2 months after iron addition, the concentrations of $\mathrm{HCl}-\mathrm{Fe}$, total $\mathrm{P}$, and total sulfide in the upper $2.5 \mathrm{~cm}$ of sediment were higher and more variable in the iron addition plots relative to the initial sediment concentrations and to controls (Fig. 4). In July, after 8 months, the effect had extended down-core to a depth of $10 \mathrm{~cm}$, perhaps due to geochemical migration, bioturbation, or both. Although pore-water sulfide concentrations were not measured, free sulfide could not be detected by smell in the upper $10 \mathrm{~cm}$ of sediment from iron addition 


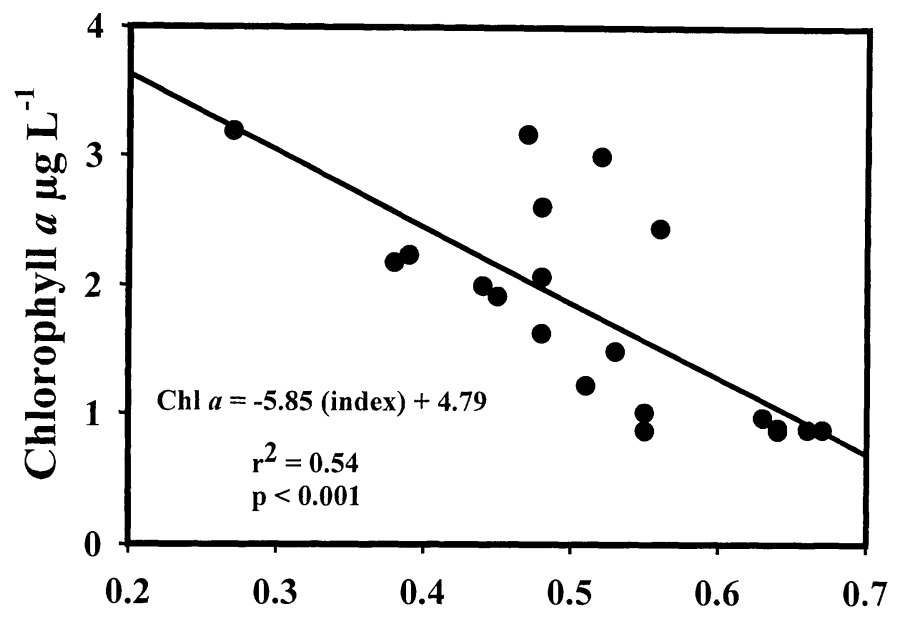

Index of iron availability

Fig. 3. Plot of water column Chl $a$ concentration versus the sediment index of iron availability in Florida Bay.

plots. We also observed differences in the amounts of $\mathrm{Fe}, \mathrm{P}$, and $\mathrm{S}$ below the zone of influence of iron additions. For example, the down-core concentrations of sulfur in iron addition and control plots were measured up to $60 \mu \mathrm{mol} \mathrm{\textrm {g } ^ { - 1 }}$
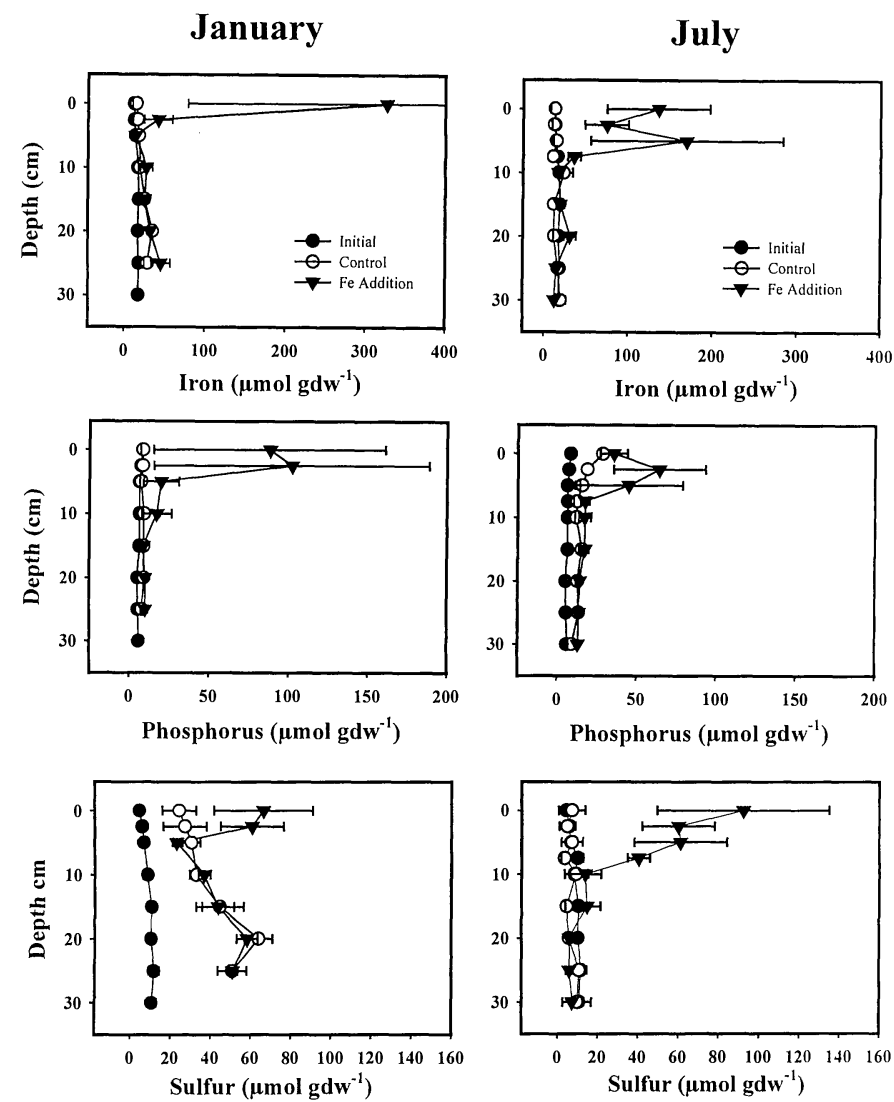

Fig. 4. Results of iron addition to carbonate sediments on $\mathrm{HCl}-$ $\mathrm{Fe}$, total $\mathrm{P}$ and $\mathrm{S}$ profiles. Data from control and experimental plots 2 and 8 months after iron additions (in January and July, respectively) are plotted along with data collected prior to iron addition.
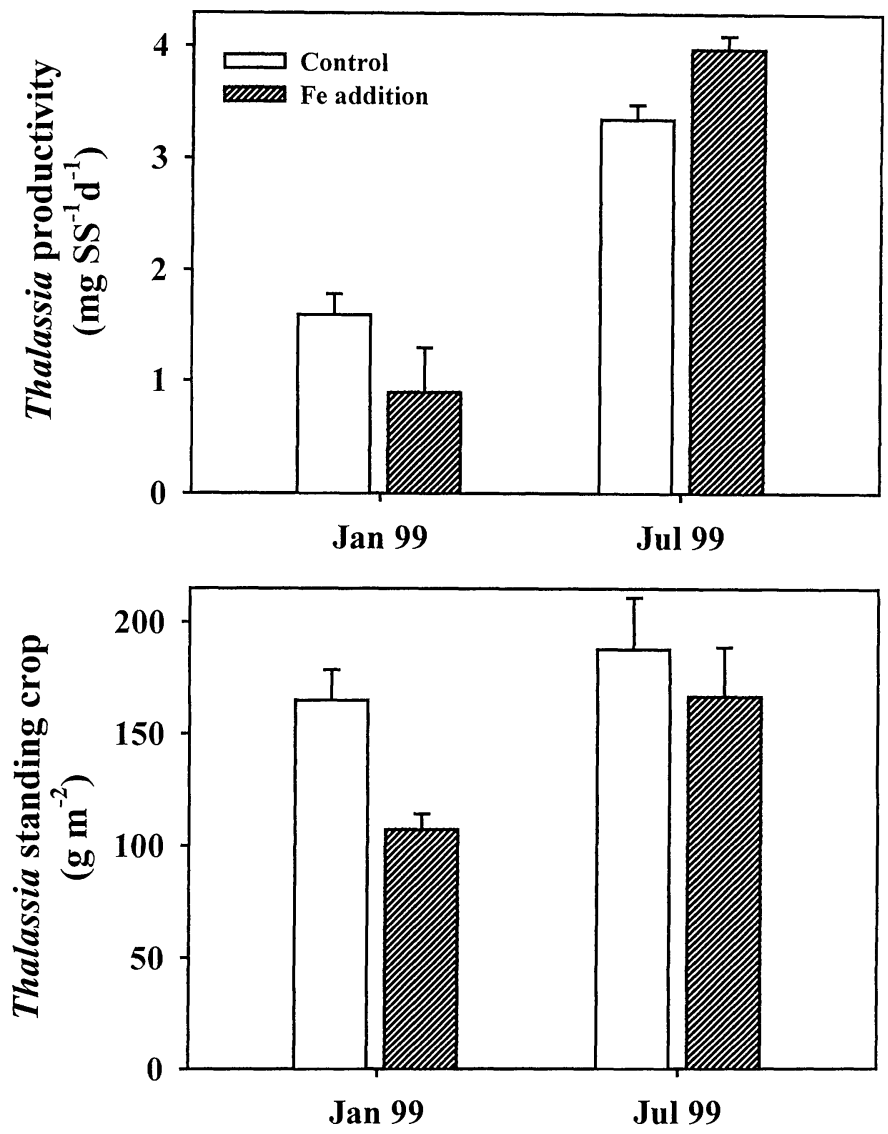

Fig. 5. Standing crop and productivity of Thalassia testudinum, 2 and 8 months after iron additions in January and July, respectively.

DW in January but were less than $20 \mu \mathrm{mol} \mathrm{g}{ }^{-1}$ DW in July. Also, sediments from both experimental and control plots were higher in phosphorus relative to initial conditions measured in November.

The measured response of the seagrass $T$. testudinum to iron enrichment was variable. Short shoot productivity was significantly higher in iron addition plots in July during the growing season ( $t$-test, $t=-3.6$, df $4, P=0.02$ ) (Fig. 5). In contrast, seagrass standing crop was significantly lower in iron addition plots in January $(t=3.764, P=0.02)$, with no difference between iron addition and control plots in July $(t=0.558, P=0.61)$.

The iron content of T. testudinum leaves was significantly higher in the iron addition plots in both January and July (ANOVA, TREATMENT main effect, $F=7.2, P=0.02$ ) (Fig. 6). Leaf iron content decreased from January to July (ANOVA, TIME main effect, $F=8.0, P=0.01$ ). The seagrass $H$. wrightii colonized both experimental and control plots between January and July. In July, the iron content of $H$. wrightii also was higher in the iron addition plots ( $t$-test, $t=-2.85$, df $4, P=0.05$ ).

The phosphorus content of leaves of $T$. testudinum was higher in July than January (ANOVA, TIME main effect, $F$ $=9.7, P=0.01)$, but the $\mathrm{P}$ content of leaves from the iron addition plots and control plots was not significantly different (ANOVA, TREATMENT main effect, $F=0.58, P=$ 

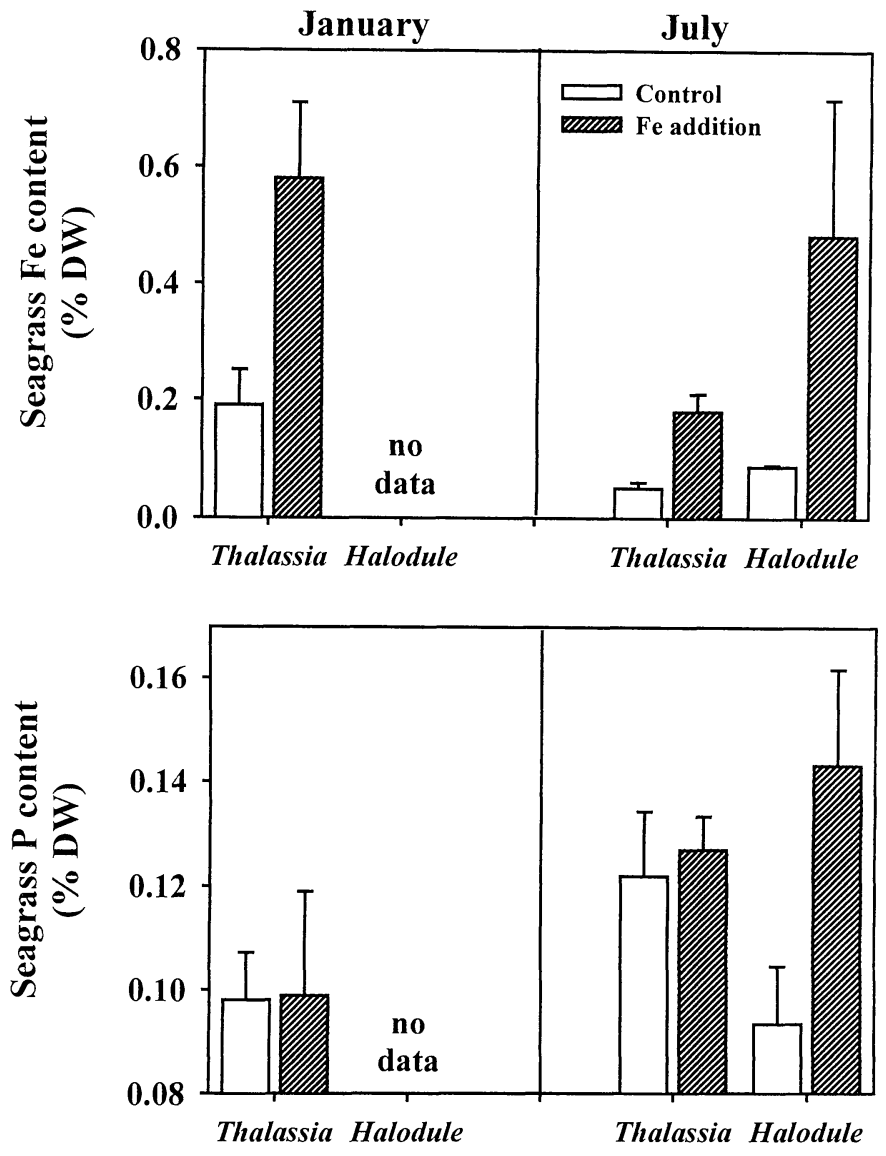

Fig. 6. Iron and phosphorus content of leaf tissue from Thalassia testudinum and Halodule wrightii, 2 and 8 months after iron additions in January and July, respectively.

0.46), nor was there a significant TIME by TREATMENT interaction (ANOVA, $F=0.004, P=0.95$ ) (Fig. 6). The $\mathrm{P}$ content of $H$. wrightii leaves collected in July was higher from iron addition plots at $\mathrm{P}=0.08$ ( $t$-test, $t=-2.287, \mathrm{df}$ 4).

Both sampling time and iron addition had a marked effect on the sulfur isotopic composition of seagrass leaves (Fig. 7). The $\delta^{34} \mathrm{~S}$ signature of $T$. testudinum was higher in July than January in control plots (ANOVA, TIME main effect, $F=65.7, P=0.001)$. The $\delta^{34} \mathrm{~S}$ signature also was higher in iron addition plots (ANOVA, TREATMENT main effect, $F=63.9, P=0.001$ ). In January, $T$. testudinum leaves from control plots had an average $\delta^{34} \mathrm{~S}$ of $-2.6 \pm 1.4 \%$ compared to $+6.7 \pm 1.2 \%$ in iron addition plots. In July, T. testudinum leaves from iron addition plots also were isotopically heavier than leaves from control plots $(+12.3 \pm 0.2 \%$ compared to $+6.7 \pm 0.2 \%$ ) . Compared to $T$. testudinum, leaves of $H$. wrightii were more enriched in ${ }^{34} \mathrm{~S}$ (Fig. 7); in July, the isotopic signature of $H$. wrightii leaves from iron addition plots was higher than control plots $(+19.9 \pm 0.4 \%$ o compared to $+11.3 \pm 0.4 \%$; $t$-test, $t=-14.2$, df $2, P=0.005)$.

\section{Discussion}

The fine-grained carbonate sediments of our study area in southern Florida are of biogenic origin. The most important

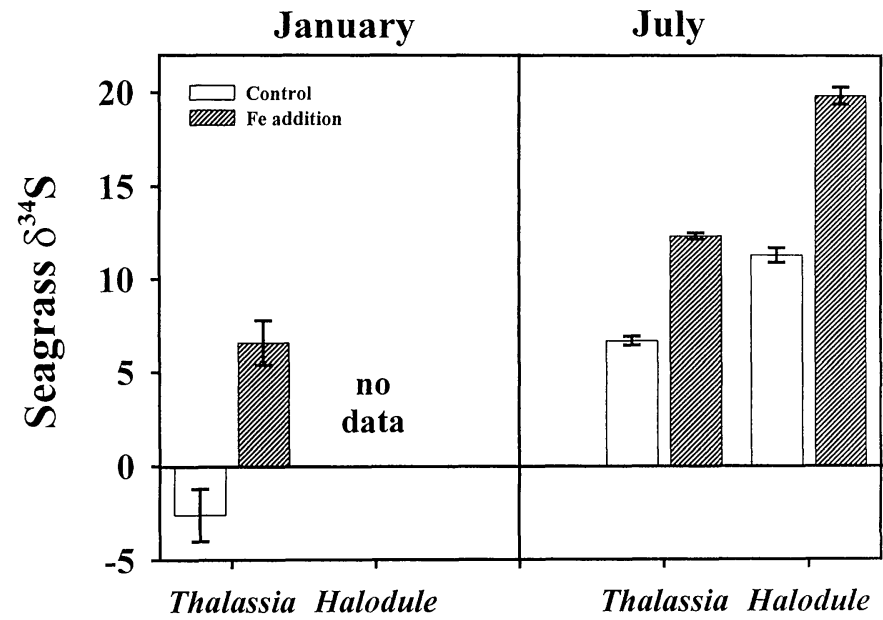

Fig. 7. $\delta^{34} \mathrm{~S}$ signature of seagrass leaves from Thalassia testudinum and Halodule wrightii, 2 and 8 months after iron additions in January and July, respectively.

organisms contributing skeletal remains to this sediment include calcareous green algae, seagrass epiphytes (spirorbid polychaetes, soritid foraminiferans, encrusting coralline algae), mollusks, and stony corals (Nelsen and Ginsburg 1986; Bosence 1989; Frankovich and Zieman 1995). Iron distribution in these sediments, however, is somewhat variable and the mechanisms for depositing iron and generating its observed distributions in south Florida hydroscape are not well known. First, the concentrations of iron are fairly high relative to other carbonate environments (Duarte et al. 1995; Koch et al. 2001), although not relative to terrigenous sediments (e.g., Chambers et al. 2000). In Florida Bay, the iron gradient decreasing away from the Florida mainland suggests a continental, clastic source (Eugene Shinn pers. comm.), possibly derived from transport through the Everglades. The more patchy distribution of iron in sediments from the southwest Florida shelf may be indicative of a nonuniform source of iron or sediment redistribution by water currents, eolian transport, or other physical process (e.g., Muhs et al. 1990; Duce and Tindale 1991).

Based on our results, total Fe and $\mathrm{P}$ exhibit similar patterns of abundance in shelf sediments. Using a different extraction scheme, Yarbro et al. (pers. comm.) found that $\mathrm{Fe}$ and $\mathrm{P}$ species were positively correlated in Florida Bay sediments. We view the covariation in $\mathrm{Fe}$ and $\mathrm{P}$ from shelf sediments (Fig. 1) and from bay sediments (Yarbro et al. 1997) as evidence that $P$ concentration is to some extent associated with $\mathrm{Fe}$ availability, even in iron-poor carbonate environments where $\mathrm{P}$ sorption to calcium carbonate minerals is the principal geochemical mechanism influencing aqueous phosphorus concentrations (Morse et al. 1985). We observed a decreasing gradient in sediment $\mathrm{P}$ from west to east across Florida Bay, consistent with previous work documenting phosphorus limitation of seagrass biomass and production along the same gradient (Fourqurean et al. 1992a).

The computed index of iron availability was lowest in the north-central basin of Florida Bay, a region where extensive seagrass die-off occurred over a decade ago (Fourqurean and 
Robblee 1999). The low index could be either a cause or a consequence of seagrass die-off, but the fact that a majority of sediment $\mathrm{Fe}$ in this region has been used for $\mathrm{Fe}-\mathrm{S}$ mineral formation suggests a strong linkage between seagrass production/decomposition and sediment $\mathrm{Fe}-\mathrm{S}$ geochemistry. Furthermore, this linkage extends to the water column, where we found a significant negative correlation between sediment iron availability and water column primary production. Our interpretation of these data is that with a reduction in sediment iron availability via seagrass decomposition, mineralized or iron-bound phosphorus can migrate from the sediment to the water column, thereby promoting algal production in the north-central basin (e.g., Phlips et al. 1999). Rather than phytoplankton being iron-limited (Martin and Fitzwater 1988), we speculate that low availability of reactive iron in surface sediments occurs where diffusion of $\mathrm{P}$ into the water column stimulates algal blooms. In these areas, anaerobic decomposition of labile organic matter may release more $\mathrm{P}$ than can be biogeochemically retained in the sediments and may generate sufficient sulfide to deplete the reactive iron pool. Studies of nutrient flux between sediment and water column are required to test the effects of decreased iron availability.

What are the ramifications of increased iron availability in sediments? First, the sediment pool of $\mathrm{P}$ was increased by iron addition, but we are not sure whether this $\mathrm{P}$ was available for seagrass growth. We measured a significant change in foliar P for T. testudinum between sampling dates but saw no significant difference between control and iron addition plots (Fig. 6). Even though more total P was retained in sediments, P may have been in a form inaccessible by $T$. testudinum (e.g., sorbed to iron or carbonate minerals). In contrast, iron addition led to significantly greater iron uptake by seagrass, but tissue $\mathrm{Fe}$ was lower in July than in January. The decrease in foliar Fe from iron addition plots probably was due to the increased iron-sulfide mineral production during the growing season (Fig. 4).

Using the depth-integrated accumulation of sulfide minerals in iron addition plots, we calculated a sulfide deposition rate of approximately $130 \mu \mathrm{mol} \mathrm{cm} \mathrm{cm}^{-2}$ in 8 months. This amount of sulfide buffering is comparable to an estimated sulfate reduction rate of $200 \mu \mathrm{mol} \mathrm{cm}{ }^{-2} \mathrm{yr}^{-1}$ in vegetated carbonate sediments of Florida Bay (Ku et al. 1999). In other words, a significant portion of the pore-water sulfide poolmeasured $>1 \mathrm{mM}$ at our experiment location by Carlson et al. (1994) —-was sequestered by sulfide mineral formation in iron addition plots. With isotopically lighter sulfide removed from pore water, a heavier combined sulfate + sulfide pool was available for uptake by seagrasses in iron addition plots relative to controls (Fig. 7). All $\delta^{34} \mathrm{~S}$ signatures were less than surface seawater $(+21)$, however, suggesting the influence of active sulfate reduction/oxidation cycles in the root zone, bacterial disproportionation of elemental sulfur (Canfield and Thamdrup 1994), or both. Furthermore, the lighter seagrass $\delta^{34} \mathrm{~S}$ values in January vs. July may reflect a seasonal shift in the relative importance of sulfide oxidation; light sulfide precipitated as pyrite during the summer growing season may be reoxidized during the winter, generating lighter sulfate for root uptake (Stribling et al. 1998).

Whether by iron-mediated pyrite formation or other pro- cesses, lower pore-water sulfide concentrations in vegetated sediments would provide obvious benefits to seagrasses sensitive to sulfide (Erskine and Koch 2000). Owing to nonhomogeneity of seagrass density at the initiation of the experiment, however, $T$. testudinum standing crop actually was lower in the iron addition plots in January. An increase in standing crop to the level of control plots may have reflected the observed faster growth rate of $T$. testudinum shoots in the iron addition plots in July (Fig. 5).

Colonization of control and iron addition plots by $H$. wrightii allowed for a comparison of the response of two seagrass species to iron additions. $H$. wrightii has a less robust root and rhizome system than $T$. testudinum, and its rhizomes are not buried as deeply in the sediment as T. testudinum $(\sim 3-5 \mathrm{~cm}$, compared to $\sim 20 \mathrm{~cm}$ at our experimental site). For both species, foliar $\mathrm{Fe}$ was higher in iron addition plots, indicating that dissolved Fe was more available for root uptake. In contrast to T. testudinum, however, $\mathrm{P}$ content of $H$. wrightii was higher in the iron addition plots (at $P=0.08$ ) (Fig. 6), suggesting greater $\mathrm{P}$ availability to $H$. wrightii. Also, H. wrightii was isotopically heavier than T. testudinum, consistent with the presumed species differences in sulfide exposure. The more shallow-rooted $H$. wrightii was exposed to lower sulfide concentrations; hence, the ${ }^{34} \mathrm{~S}$ signature in $\mathrm{H}$. wrightii leaves was heavier than deeply rooted $T$. testudinum. In the one previous comparison of the sulfur isotopic content of these two species, H. wrightii was more enriched with ${ }^{34} \mathrm{~S}$ than $T$. testudinum (Fry et al. 1982). These results demonstrate that deep- and shallowrooted seagrasses are responding to environmental conditions at different depths in the sediment (Williams 1990).

Seagrasses from the south Florida hydroscape do not seem iron-limited; foliar concentrations of iron from control plots in Florida Bay were above the critical level for iron limitation suggested by Duarte et al. (1995), and in fact, foliar $\mathrm{Fe}$ actually decreased during the growing season. Furthermore, the absence of an increase in $\mathrm{P}$ content of the dominant seagrass and only a modest increase in individual shoot growth rates indicate that iron enrichment did not enhance $\mathrm{P}$ availability for $T$. testudinum. Even with iron-controlled alleviation of sulfide stress, we suspect that $\mathrm{P}$ limitation exerts a primary control on T. testudinum production in carbonate sediments. More research is necessary to determine whether the indirect, geochemical effects of iron additions significantly influence primary production of shallow-rooted seagrass species like $H$. wrightii and of benthic algae.

Iron concentrations in sediments of Florida Bay and the southwest Florida shelf are variable and low relative to terrigenous sediments but are high relative to other studied carbonate environments. Still, sediment pyrite formation is ironlimited. In Florida Bay, the calculated index of sediment iron available to buffer toxic sulfides correlates negatively with water column Chl $a$, indicating a strong benthic-pelagic coupling in this shallow subtropical embayment. Addition of iron to vegetated sediments increases pyrite mineral formation, reduces plant exposure to sulfide, and stimulates individual shoot growth of $T$. testudinum. Iron addition also increases sediment $\mathrm{P}$ but does not appear to increase availability sufficiently to overcome $\mathrm{P}$ limitation of seagrass production. 


\section{References}

BARber, R. T., AND F. P. Chavez. 1991. Regulation of primary productivity in the equatorial Pacific Ocean. Limnol. Oceanogr. 36: $1803-1815$.

BARBER, T. R., AND P. R. CARLSON, JR. 1993. Effects of seagrass die-off on benthic fluxes and porewater concentrations of $\Sigma \mathrm{CO}_{2}, \Sigma \mathrm{H}_{2} \mathrm{~S}$, and $\mathrm{CH}_{4}$ in Florida Bay sediments, p. 530-550. In R. S. Oremland [ed.], Biogeochemistry of global change: Radiatively active trace gases. Chapman and Hall.

BERner, R. A. 1984. Sedimentary pyrite formation: An update. Geochim. Cosmochim. Acta 48: 605-615.

Bosence, D. 1989. Surface sublittoral sediments of Florida Bay. Bull. Mar. Sci. 44: 434-453.

Boyer, J. N., J. W. Fourqurean, And R. D. Jones. 1997. Spatial characterization of water quality in Florida Bay and Whitewater Bay by multivariate analyses: Zones of similar influence. Estuaries 20: 743-758.

- J. W. Fourqurean, AND R. D. Jones. 1999. Seasonal and long-term trends in water quality of Florida Bay (1989-1997). Estuaries 22: 417-430.

CANFIEld, D. E., AND B. Thamdrup. 1994. The production of ${ }^{34} \mathrm{~S}-$ depleted sulfide during bacterial disproportionation of elemental sulfur. Science 266: 1973-1975.

Carlson, P. R., Jr., AND J. Forrest. 1982. Uptake of dissolved sulfide by Spartina alterniflora: evidence from natural sulfur isotope abundance ratios. Science 216: 633-635.

- L. A. YARBro, AND T. R. BARBER. 1994. Relationship of sediment sulfide to mortality of Thalassia testudinum in Florida Bay. Bull. Mar. Sci. 54: 733-746.

Chambers, L. A., And P. A. Trudinger. 1979. Microbiological fractionation of stable sulfur isotopes: A review and critique. Geomicrobiol. J. 1: 249-293.

Chambers, R. M., J. T. Hollibaugh, and S. M. Vink. 1994. Sulfate reduction and sediment metabolism in Tomales Bay, CA. Biogeochem. 25: 1-18.

- J. W. Fourqurean, J. T. Hollibaugh, and S. M. Vink. 1995. Importance of terrestrially-derived, particulate phosphorus to phosphorus dynamics in a west coast estuary. Estuaries 18: $518-526$.

, J. T. Hollibaugh, C. S. Snively, and J. N. Plant. 2000. Iron, sulfur and carbon diagenesis in sediments of Tomales Bay, California. Estuaries 23: 1-9.

CoAle, K., AND The IronEx GRoup. 1996. A massive phytoplankton bloom induced by an ecosystem-scale iron fertilization experiment in the equatorial Pacific Ocean. Nature 383: 495-501.

Duarte, C. M., M. Merino, And M. Gallegos. 1995. Evidence of iron deficiency in seagrasses growing above carbonate sediments. Limnol. Oceanogr. 40: 1153-1158.

Duce, R. A., And N. W. Tindale. 1991. Atmospheric transport of iron and its deposition in the ocean. Limnol. Oceanogr. 36: $1715-1726$.

ERFTEMEIJER, P. L. A. 1994. Differences in nutrient concentrations and resources between seagrass communities on carbonate and terrigenous sediments in South Sulawesi, Indonesia. Bull. Mar. Sci. 54: 403-419.

ERskine, J. M., AND M. S. KoCH. 2000. Sulfide effects on Thalassia testudinum carbon balance and adenylate energy charge. Aquat. Bot. 67: 275-285.

Fourqurean, J. W., AND M. B. RobBleE. 1999. Florida Bay: A history of recent ecological changes. Estuaries 22: 345-357.

- J. C. ZiEman, AND G. V. N. Powell. 1992a. Relationships between porewater nutrients and seagrasses in a subtropical carbonate environment. Mar. Biol. 114: 57-65.

1992b. Phosphorus limitation of primary production in Florida Bay: Evidence from the $\mathrm{C}: \mathrm{N}: \mathrm{P}$ ratios of the dominant seagrass Thalassia testudinum. Limnol. Oceanogr. 37: 162-171.

, R. D. JONES, AND J. C. ZiEMAn. 1993. Processes influencing water column nutrient characteristics and phosphorus limitation of phytoplankton biomass in Florida Bay, FL, USA: Inferences from spatial distributions. Estuar. Coast. Shelf Sci. 36: $295-314$.

Frankovich, T. A., AND J. C. ZiEMAN. 1995. A comparison of methods for the accurate measurement of epiphytic carbonate. Estuaries 18: 279-284.

Fry, B., R. S. SCANLON, J. K. Winters, and P. L. Parker. 1982. Sulfur uptake by salt grasses, mangroves and seagrasses in anaerobic sediments. Geochim. Cosmochim. Acta 46: 11211124.

Geider, R. J., J. La Roche, R. M. Greene, and M. Olaizola. 1993. Response of the photosynthetic apparatus of Phaeodactylum tricornutum (Bacillariophyceae) to nitrate, phosphate or iron starvation. J. Phycol. 29: 755-766.

Jensen, H. S., K. J. McGlathery, R. Marino, and R. W. HoWARTH. 1998. Forms and availability of sediment phosphorus in carbonate sand of Bermuda seagrass beds. Limnol. Oceanogr. 43: $799-810$.

Koch, M. S., R. E. Benz, And D. T. Rudnick. 2001. Solid-phase phosphorus pools in highly organic carbonate sediments of north-eastern Florida Bay. Estuar. Coast. Shelf Sci. 52: 279291.

Ku, T. C. W., L. M. Walter, M. L. Coleman, R. E. Blake, and A. M. Martin. 1999. Coupling between sulfur recycling and syndepositional carbonate dissolution: Evidence from oxygen and sulfur isotope compositions of pore water sulfate, South Florida platform, U.S.A. Geochim. Cosmochim. Acta 63: 2529-2546.

Martin, J. H., AND S. E. FitzWATER. 1988. Iron deficiency limits phytoplankton growth in the north-east Pacific subarctic. Nature 331: 341-343.

Morse, J. W., J. J. Zullig, L. D. Bernstein, F. J. Millero, P. Milne, A. Mucci, And G. R. Choppin. 1985. Chemistry of calcium carbonate-rich shallow water sediments in the Bahamas. Am. J. Sci. 285: 147-185.

Muhs, D. R., C. A Bush, K. C. Stewart, T. R. Rowland, and R. CRitTEnden. 1990. Geochemical evidence of Saharan dust parent material for soils developed on Quaternary limestones of Caribbean and western Atlantic islands. Quat. Res. 33: 157177.

Nelsen, J. E., JR., AND R. N. GinsbuRg. 1986. Calcium carbonate production by epibionts on Thalassia in Florida Bay. J. Sediment. Petrol. 56: 622-628.

Phlips, E. J., S. BADYlaK, AND T. C. LyNCH. 1999. Blooms of the picoplanktonic cyanobacterium Synechococcus in Florida Bay, a subtropical inner-shelf lagoon. Limnol. Oceanogr. 44: 11661175.

Powell, G. V. N., W. J. Kenworthy, and J. W. Fourqurean. 1989. Experimental evidence for nutrient limitation of seagrass growth in a tropical estuary with restricted circulation. Bull. Mar. Sci. 44: 324-340.

RosENFIELD, J. K. 1979. Interstitial water and sediment chemistry of two cores from Florida Bay. J. Sediment. Petrol. 49: 989994.

Stribling, J. M., J. C. Cornwell, and C. Currin. 1998. Variability of stable sulfur isotope ratios in Spartina alterniflora. Mar. Ecol. Prog. Ser. 166: 73-81.

TERRADOS, J., AND OTHERS. 1999. Are seagrass growth and survival constrained by the reducing conditions of the sediment? Aquat. Bot. 65: 175-197.

WiLliams, S. L. 1990. Experimental studies of Caribbean seagrass bed development. Ecol. Monogr. 60: 449-469. 
Wu, J., W. Sunda, E. A. Boyle, And D. M. Karl. 2000. Phosphate depletion in the western North Atlantic Ocean. Science 289: 759-762.

ZiEman, J. C. 1974. Methods for the study of the growth and production of turtle grass, Thalassia testudinum. Aquaculture 4: 139-143.

, J. W. Fourqurean, and T. A. Frankovich. 1999. Sea- grass die-off in Florida Bay: Long-term trends in abundance and growth of turtle grass, Thalassia testudinum. Estuaries 22: $460-470$

Received: 29 November 2000 Amended: 28 March 2001 Accepted: 23 April 2001 